\title{
Advancing the Case for the Support and Promotion of African Immigrant- Owned Businesses in South Africa
}

\author{
Dr. Robertson K. Tengeh \\ Faculty of Informatics and Design, \\ Cape Peninsula University of Technology. \\ Email:rtengeh@yahoo.com.
}

\section{Doi:10.5901/mjss.2013.v4n2p347}

\begin{abstract}
Drawing on the literature on the support of small businesses and case studies, this article advances the case for the support of African immigrant owned businesses in South Africa which is currently neglected. In the past justification for the institution of support policies in favour of small businesses was predominantly based on the fact that they disproportionately encountered more obstacles than their larger counterparts. Shying away from the traditional "business focus" justification for the support of small business, this study advances an "owner focus" justification - one that is based on the unique needs of the owner, rather than that of the business itself. Following similar logic, given that most immigrants start small businesses as a means of survival in their host countries, this study advances an even more compelling reason why immigrant owned businesses should be supported. Acknowledging the role that a supported small business sector in general and immigrant owned business in particular can play in the economy and taking steps to strengthen this sector would be in the right direction for the South Africa government.
\end{abstract}

Key words: Small business support, immigrant- owned business, South Africa

\section{Introduction}

Since the advent of democracy in 1994, South Africa has witnessed an unprecedented influx of foreign nationals into the country (Landau \& Jacobsen, 2004). It is not clear how many immigrants are in South Africa today. There seem to be inconsistencies in the numerous reports that have attempted to document the number of immigrants in South Africa (CDE, 2006). Given that a majority of these immigrants enter the country covertly, Maharaj (2004) notes that it becomes almost impossible for the government and researchers to accurately document them.

The reintegration of South Africa into the world economy attracted immigrants of different categories, from far and wide. A majority of these immigrants, especially from African countries hoped to better their lives once in South Africa. Limited job opportunities in South Africa push immigrants into starting their own businesses (Tengeh, et al., 2011). However, these immigrants have to overcome numerous obstacles in order to start-up or make a success of their businesses (Oliveria, 2008; Tengeh et al., 2011). For those that do, they experience improvements in their lives and the struggle continues for those that do not. For South Africa as a nation, a successful adaptation of these immigrants into the mainstream economy may result in positive spin-offs in the form of economic growth, employment and poverty reduction (Chandra et al., 2001), all things being equal. At the citizenry level (individual level), their smooth adaptation is met with detest as they are perceived to be a threat given the scarcity of resources (economic) currently confronting the South African government. In view of the foregoing, we perceive a government caught between two extremes. On the one hand, whether to stretch resources to accommodate immigrants without plunging the country into financial distress as witnessed by some European countries in recent years, thereby delineating the populace. On the other extreme, the government feels indebted to these immigrants on humanitarian grounds as evident in signed international conventions. How does the government manage these extremes? Evidence from other countries, for instance Portugal and the United States of America, all attest to the fact that a properly managed and integrated immigrant community can be an asset to the host country from an entrepreneurial perspective (Oliveira, 2008).

Having adapted an approach to immigrant adaptation that grants them the right to self-employment rather than paid employment or handouts through refugee grants as practiced in most European countries, their full adaptation will 
benefit the country as a whole from a "system's approach".

With a significant proportion of these immigrants not keen on leaving the country any time soon, it is time that South Africa did something to facilitate their adaptation to the country. A proposition that may be backed by the increasing number of South African studies that have highlighted the important contribution these immigrants can make to the economy from an entrepreneurial perspective and the apparent obstacles that they face doing so (Tengeh et al., 2011). Leveling the playing field may be a necessary step for the South African government.

This study is part of a broader study that was conducted on African immigrant-owned businesses in South Africa. The study revealed that although African immigrants faced problems ranging from lack finance, business space to inappropriate residence permits, they are less likely to benefit from the existing small business support structures (Tengeh, et al, 2011). The current small business support landscape is one that discriminates against immigrants in that they cannot access the much needed support. This is partly due discriminatory policies and the negative perceptions of immigrants held by a cross section of the South African society. Of particular importance is the very temporary nature of the residence permits granted African immigrants which makes it impossible for them to gain employment and benefit from the current business support initiatives. This theoretical paper focuses on Small, Medium and Micro Size Enterprises (SMMEs) given that an overwhelming majority of immigrant-owned businesses in South Africa fall within this category.

Although there is significant literature that projects the plight of African immigrants in terms of the obstacles that they face in starting and operating a business in South Africa (Tengeh et al 2011; Fatoki \& Patswawairi, 2012) there is limited literature justifying why immigrant-owned businesses need to be supported, if not for the fact that they small businesses.

To justify the need for the support or non-support of African immigrant owned businesses, we begin by placing our argument within the context of the historical development and the importance of small businesses, given the fact that most African immigrant owned businesses in South Africa fall within this cohort.

\section{The historical development and importance of Small Businesses}

The SMMEs sector and the position that it holds today, in both the developed and developing countries, has evolved over time. This evolution has been greatly influenced by the economic conditions and political ideologies held at any given time. Just as large business was conceived to be the conduit of industrialisation and economic growth in the early 1970s, so too today is small business seen by many as the medium through which economic and social development can be achieved (Sinha, 2003; Gebremariam et al, 2004).

Prior to the 1970s, and particularly between 1935 and 1968, the overwhelming majority of businesses in most developed countries, including the United Kingdom (UK) and the United States of America (USA) could be classified as small businesses (Bannock, 1981). To gain competitive advantage in world trade, the government of the USA and that of the UK got more involved in the activities of their economies (Bannock, 1981) with the resultant reorganisation through mergers and conglomerates of small enterprises into larger ones. One may suggest, that this move was prompted by the need to curb unemployment and to generate favourable media attention.

At that time, the shift in strategy in favour of big enterprises led to a reduction in the number as well as the importance of small enterprises. Bannock (1981) believes that it was the need to counter the American strategy (competitive advantage), that prompted most European countries to follow suit with the reorganisation into larger units of their small enterprises. The sudden change in economic strategy was not limited to developed nations. In Africa, like in Britain and America, most countries at independence in the early 1960s saw industrialisation as the central way to move away from the colonial pattern of dependence on imported manufactured and primary exports (Hansohm, 1992). According to Osmani (2003), the inward-looking import substitution strategy of industrialisation followed by most Less Developed Countries (LDCs) created an incentive structure that fostered capital intensive production at the expense of reducing employment potential. As such when the opportunity came, the LDCs quickly copied or were forced to replace small enterprises with large ones. In South Africa, and particularly during the apartheid era, the government through biased policies and programmes tilted the shift in balance in favour large firms (UNDP, 2003).

The growing pattern of making the large enterprises the driving force of economies was put to test after the 1973 oil crises, which saw the collapse of the world economy. According to Bannock (1981), the increase in oil prices gave an upward twist to the inflationary spiral and although there was unemployment among men and machines, governments could not stimulate demand for fear of pushing inflation still higher. He adds that when finally inflation was abated in 1974, all kinds of firms and activities that had been sustained primarily by the continuous inflation were suddenly exposed to the "chill wind" of contraction - resulting in the vast resources of men and capital being tied up in large industries while small 
firms experienced shortages. In recent times, the economics of scale that was believed to be a distinct advantage held by big business has gradually been eroded by the emergence of computer-based technology in production, administration, and information (Gebremariam et al., 2004).

From an African perspective, Hansohm (1992) adds that the decline in growth and capacity utilisation of large firms that accompanied the post-world war period is an indication that the industrialisation process resorted to at independence was neither sustainable nor representative of a real transformation of the African economy.

More recently, many studies (Dockel, 2005; Harvie, 2005; Agupusi, 2007) have noted a shift in industry structure away from greater concentration and centralisation towards less concentration and decentralisation - a shift towards an increased role for small firms. According to Gebremariam et al (2004) this is mainly due to changes in production technology, consumer demand, labour supply, the pursuit of flexibility, and efficiency. These factors, in turn, have led to the restructuring and downsizing of large enterprises and the entry of new firms. Gebremariam et al (2004) further suggest that the alternative view today is that small business is the key element and driving force in generating employment and realising economic development. This paradigm shift has, in turn, brought a revival in the promotion of small businesses and entrepreneurial initiative at local, national and international levels. Accompanying the revival, small businesses have been the infusion of new ethnic owners into the ranks of petty proprietorship (Waldinger et al., 1990). The question that is not specifically addressed in the foregoing discussion is whether the South African SMME sector followed a similar pattern like that of the majority of its African counterparts.

\section{The SMME Sector in South Africa}

South Africa like its African counterparts went through similar periods during which big businesses were overrated and those during which emphasis was placed on the development of small businesses (the current scenario). It is not clear how pure economic motives and political manoeuvres such as the apartheid policies interplay to influence the historical development of the SMME sector. However, the current scenario is one in which emphasis is placed on the development of the SMMEs although amidst the numerous challenges that need to be overcome.

According to the DTI (1995) and Dockel (2005), it has been recognized all over the world that the small business sector plays an important role in the socioeconomic development of a country and hence there is a need to support its development. Like other countries, South Africa has also felt the urge to promote the SMME sector. The DTI (1995) claims that the SMME sector in South Africa was grossly neglected during much of the previous two centuries following the discovery of diamonds and gold, and then the establishment of a modern, capitalist economy with almost exclusive white control. SACOB (1999) posits that the growth and development of the SMME sector is of critical importance to South Africa's ability to address the serious problems of unemployment, income inequality, economic concentration, lack of international competitiveness, and low economic growth, which confront it. Concurring with SACOB, Lloyd (2002) maintains that it is from this angle that the South African government sees SMMEs as the logical 'kick start' mechanism for job creation and the future prosperity of the country, and is therefore committed to their development.

The economic structure of the formal sector in South Africa resembles that of many industrialised nations, with the primary sector, agriculture and mining contributing relatively little to the GDP. For instance, the tertiary sector contributes $69 \%$ of the GDP (Ntsika, 2000:24). Despite the fact that the statistical base of SMMEs in South Africa is still poor (Chalera, 2006), there is little doubt about their relative significance. According to the DTI (1995), there are more than 800 000 SMMEs in South Africa, absorbing about a quarter of the labour force of 15 million people. This is in addition to about 3,5 million people involved in some or other types of survivalist enterprise activities. Ntsika (20004) adds that, in addition to being accountable for $54,5 \%$ of all formal private sector employment, SMMEs account for $34,8 \%$ of the GDP. SMMEs also make significant contributions to the number of establishments as well as to salaries and wages. Ntsika (2000) notes a drop as SMMEs now contribute $42,7 \%$ (as against $57,3 \%$ for large firms) of the total value of salaries and wages paid.

The DTI (1995) is of the opinion that, while the importance of large industrial, mining, and other enterprises for the growth of the economy cannot be denied, there is enough evidence that the labour absorptive capacity of small businesses is high, the average capital cost per job created is usually lower than in big business, and its role in technical and other innovations is vital for many of the challenges facing South Africa's economy. Luiz (2001) believes that the small business sector in South Africa has the potential to contribute to job creation and economic growth, whilst at the same time redressing historical imbalances and increasing black economic participation. The current state of economic participation of black South Africans is of great concern. According to SACOB (1999), it is clear from official employment figures that the SMME sector has not been able to absorb all of the jobs shed by large scale enterprises or to assist in 
reducing the overall level of unemployment in South Africa. This may be attributed to the obstacles inhibiting the growth of this sector.

\section{Growth constraints in the South African SMME sector}

There can be no doubt that, compared to big businesses in South Africa and other countries, small businesses face a wider range of constraints and problems and are less likely to address these problems on their own, even in effectively functioning market economies (DTI, 1995). The constraints, amongst others, relate to the legal and regulatory environments confronting SMMEs, access to markets, providing finance and business premises (at affordable rentals), the acquisition of skills and managerial expertise, access to appropriate technology, the quality of business infrastructure in poverty areas, and the tax burden in some case. In the South African context, the constraints have been particularly hard for entrepreneurs in rural areas and women entrepreneurs.

In a World Bank study of 155 countries on the factors that enhance or inhibit business activities (World Bank, 2006 cited in Swanepoel, 2008:49), South Africa ranked $28^{\text {th }}$ overall on the ten indicators used in the study. Based on the rankings of the World Bank, a high ranking on the ease of doing business means that a government has created a regulatory environment conducive to conducting business. A comparison of South Africa and the USA in terms of the factors that foster or hinder entrepreneurial activities suggests that it is far more time consuming and costly to establish a business in South Africa.

Turning back to within-country constraints, it is worth noting that the problems and constraints encountered differed widely between the various segments of SMMEs and between the sectors as well as the owner categories. According to the DTI (1995), although it is generally acknowledged that micro and survivalist enterprises are far less able to face constraints linked to financing, market access and the acquisition of skills, some sectors like agriculture, construction, and manufacturing confront small enterprises with a wider range of problems thus preventing easy entrance into these sectors by new enterprises. Even among medium sized enterprises, problems like international competition, technology transfer and skills training constitute major growth obstacles (DTI, 1995).

In addition to sector specific differences of constraints, the legacy of apartheid constitutes an important factor in the ability of black-owned/controlled small enterprises to face business development constraints. The DTI (1995) outlines the various ways in which the majority of South Africans, for decades, were denied access to viable business opportunities:

- Bantu education constricted opportunities for the acquisition of technical and professional skills by black people.

- There was a total absence of entrepreneurial education or sensitizing for young people in a way that could encourage them to enter business and acquire a culture of entrepreneurship.

- Apartheid confined the majority of the black South Africans to homeland areas which were not only the poorest in terms of living standards and business opportunities, but also lacked a dynamic business environment.

- Even outside the homelands, the system of apartheid made it impossible for black would-be-entrepreneurs to participate in business apprenticeships and partnerships with more established (non-black-owned/controlled) enterprises.

- Racially segregated residential areas, enforced through the Group Areas Act, not only uprooted millions of people from their places of residence and business, but also led to large capital losses and virtually destroyed the fabric of black small enterprises.

- The drastic curtailment of property ownership rights of blacks made it impossible for them to acquire assets that could serve as collateral for loan financing; it also excluded blacks from the long term processes of capital accrual and growth through rising property values and share prices.

- Apartheid left no real space for the involvement of black women; marriage laws reduced women to unions with no contractual capacity at all. Even though laws have changed, customary law remains intact and there are cultural, behavioral and attitudinal constraints which affect women's participation in business, particularly in the rural areas. There are also restrictions in terms of access to land.

From a regulatory standpoint, SACOB (1999) cites three major problems with the present labour legislation:

- It imposes significant additional direct costs on businesses

- There is a high 'hassle factor' associated with compliance.

- The legislation robs owners and managers of some of the control and flexibility which they perceive as being both desirable and necessary to the effective running of their businesses. 
Relating to finance as a constraint confronting SMMEs, South Africa is not much different to some developed and less developed countries. Here in South Africa, at first glance the issue of finance is a general one that affects most small businesses (Rogerson, 2007), although more acute for foreign nationals despite the African National Congress's (ANC) popular slogan that "South Africa belongs to all who live in it". Notwithstanding the laudable efforts made by the ANC-led government in promoting small business development, inadequate access to finance especially for business start-up remains a major issue, not only for native entrepreneurs but also for immigrants (Landau, 2010). Molapo et al (2008) posit that although the government has established a number of institutions and programmes to provide financial and nonfinancial assistance to small businesses, the impact of these programmes and institutions has not been strongly felt by those who need it most. The question one may ask is: who needs financial assistance most? The logical but debatable answer to this question would be the entire SMME tier, and entrepreneurs, in particular. Even the ANC government in its assessment of its SMMEs development programmes fifteen years after democracy, states categorically that "Micro-credit for productive purposes and access to finance is still a major impediment" (SA Presidency, 2008).

It has been argued with increasing evidence in the foregoing paragraphs that a well-managed and healthy SMME sector is a viable source of economic and social development in any economy. Since it was internationally proclaimed that SMMEs produce the bulk of employment and make huge contributions to GDP in the USA, debate around the world has been about acknowledging this role, as well as devising a policy package that will effectively strengthen SMMEs. Strengthening the position of SMMEs can be seen from two fronts namely:

- Increasing the opportunities available to entrepreneurs

- Limiting the threats to growth and survival that they face.

Identifying those opportunities that need to be strengthened and those threats that need to be limited becomes a highly contested issue. This contestation comes against the backdrop of inherent differences in a country's historical and economic background and differences in researcher perspectives over time.

As there is variation inherent in the definition and classification of SMMEs, so too are researchers and authorities divided as to what constraints this sector faces and the severity on individual members of the pack. At the theoretical level, studies have identified some of the barriers to SMMEs growth (for example see Luiz, 2001). These obstacles to SMMEs development have been seen to vary at country, national and even provincial levels. The barriers have been equally observed to vary from one sector to the other (Rogerson, 2006) in line with the gender of the owner, location of the business, and growth phase of the firm. Although SMMEs in general fall into the same category, their contribution to growth and the intensity of their problems may vary during their life cycle.

Numerous studies have been conducted to ascertain the obstacles that SMMEs face. These studies can be grouped into two categories with those that focus only on SMEs, and those that look at the SMME cluster. A common convergence in these studies is the fact that SMMEs as a sector face far more obstacles to growth than larger and more established firms. It may also be observed that the nature as well as the severity of the obstacles varies across countries, within a country, along racial lines, across sectors and even over time.

Since the advent of democracy, South Africa has increasingly seen the need for measures to strengthen the socioeconomic performance of SMMEs. Various studies have, in the process, highlighted numerous issues that need to be tackled if the South African government's ambitious goals are to be met.

- Firstly, there has been a huge debate as to whether or not intervention is necessary. Most studies in this category believe that measures should be taken to improve the overall business environment for all firms, regardless of the size of the firm, gender of the owner, location of the firm, and so forth.

- Secondly, even the studies which have acknowledged the rationale for government's intervention, nonetheless increasing disagree on the methodology (GEM, 2004). GEM (2004) notes that SMMEs are not impressed with the direct support offered by the government on the one hand. There are those who believe that the government should not distort market forces as they would, in the long run, redress those government concerns. Here it is increasingly argued that, in line with international best practice, the government should reduce direct support in favour of facilitating commercially driven private sector provision of business services (GEM, 2004). Logically, this line of argument may hold true in near perfect market conditions as may be the case in most developed countries. However, in less developed countries, and particularly South Africa where historical factors such as apartheid resulted in huge imbalances in the distribution and ownership of productive resources, market mechanisms alone may not do the honors of meeting the aforementioned government ambitions. On the other hand, researchers believe market forces have failed to address such concerns in the past and therefore there is an overwhelming need for government's direct involvement. 
- Thirdly, a fairly balanced position, increasingly held by most authors on the subject, is that governments should strike a balance between intervention and the free functioning of market forces (Biggs, 2001).

According to Brinders, Memela and Mlosy (2003), the major prerequisite for a thriving small-scale enterprise sector is an enabling environment, which includes political and economic stability, relative security, market-based incentives, and access to the resources needed to survive and grow. According to Bannock (1981) and Biggs 2001), finance has arguably been accepted to be a major obstacle to SMME growth and survival. Bannock (1981) suggests that finance is the key problem in starting a business. Although many SMMEs have limited access to capital, Nichter and Goldmark, (2009) argue that it is often unclear whether credit represents a binding constraint on firm growth. Rogerson (2006) notes that shortage of finance and/or access funds impacts upon the quality of equipment and machinery of manufacturing firms and of the services that are offered by service-based SMMEs, which in turn impact negatively on their overall productivity. The severity of finance as an obstacle, however, varies across the SMME sector.

In South Africa, a study by Chandra et al (2001) found that SMMEs are not severely constrained by lack of access to bank loans; where access is an issue it is related to the firm's size, and the age and racial group of the owner. Such differences have been found to be more acute in the rural areas than the urban areas. It has been found that although the lack of capital may inhibit the start-up process of a micro entrepreneur who has taken up the self-employment route after failing to gain paid employment (Dalago; 2003), this may not pose a major challenge to an entrepreneur who abandons paid employment to pursue self-employment as an opportunity arises. In line with Dalago's study, Rogerson (2006) found that the issue of finance was prevalent during the start-up phase regardless of the business sector. It is worth noting that the issue of finance is more acute in developing economies, where financial systems are not well developed.

In some cases, even in some well-developed financial systems, the lack of collateral (especially fixed assets) has been found to prevent SMMEs, especially micro enterprises, from getting financial assistance. In situations where financial assistance is readily available, micro enterprises may be unaware that this is the case, or the requirements for finance are too complicated, and sometimes even the threshold is too small for any profitable venture. Lack of finance as an issue becomes less felt as the SMMEs 'graduate' from a low level to a higher level. Liedholm (2001) notes that efforts to assist entrepreneurs seeking to graduate must thus address a more complex set of requirements than the simple provision of working capital.

Lack of support has also been identified as a major constraint faced by SMMEs. One may ask: Why do SMMEs need support, and what kind of support do they need? To answer these questions it has been suggested that, historically, SMMEs have been discriminated against through past economic policies that distorted the markets in favour of large enterprises (Liedholm, 2001), and even across race and gender lines. Under these distorted market conditions SMMEs and most especially micro enterprises have been found to need support if they are to efficiently contribute to economic and social development. Support may be in the form of financial assistance, skills training, and so on. In cases where these support services are available, it has been noted that low levels of awareness, especially among those who need the services most, make these services less effective. Numerous studies in South Africa have confirmed this (GEM, 2004; Chalera, 2006). In some cases, even the organizations providing the support have been noted to be less equipped and at times lack the necessary resources to be of effective service to SMMEs.

Taking into consideration the heterogeneity inherent in the SMME cluster, Dockel (2005) proposes that for policy purposes, the sector should be split into two camps, namely micro and SME, with each having its own focus, for the following reasons:

- Micro enterprises employ low skilled labour whose skills are not adequate to qualify for work in large firms (Harvie, 2005). Their productivity is relatively low. The majority of these businesses are in the service and specifically the trade sector.

- A large number of enterprises in this segment are survivalist and their numbers vary inversely with the business cycle. The size of this component tends to increase when the economy goes through slumps and decreases as the economy picks up. To some extent this component serves as a reservoir that provides a means of survival in bad times, therefore sustained employment growth and output are not likely to originate in this sector. However this does not mean that this sub-sector is not important, since it represents between $10 \%$ and $80 \%$ of all SMMEs (Dockel, 2005).

SMMEs broadly face two types of constraints. There are the internal constraints, being those retarding forces from within the sphere of influence of the enterprises itself, and the external constraints, which are from outside of the enterprise. Many obstacles to SMMEs enterprise development exist. A comprehensive summary of these obstacles is given in Hansohm (1992); the DTI (1995); Luiz (2001); Dallago (2003) and Harvie (2005). These include: 
- Lack of relevant laws and administrative procedures that undermine their legal standing and the ability to receive assistance from state agencies

- A policy bias toward large firms

- Lack of, or limited access to institutional credit

- Exclusion from participatory processes

- Imperfect market information

- Deficiencies in technical skills

- Lack of entrepreneurship

- Managerial deficiencies.

\section{Post 1994 SMME support initiatives in South Africa}

Since the establishment of the new democratic order and the acknowledgment of the significant role that a well "lubricated" small business sector can play in the economy, South Africa has made considerable efforts towards supporting and promoting small businesses. A significant step in this direction was the passing of the 1997 business Act to stimulate this process (Dockel, 2005).

Despite of South Africa's efforts, the impact of the pro small business policies have been noted by many commentators to be mix. On the one hand, a cross section of these authors (Dockel, 2005, Heintz, 2002) hold that the pro small business initiatives were successful, while on the other hand, others believe otherwise (Rogerson, 2004, SA Presidency, 2008). Amongst the reasons noted for the failure of most of the SMME initiatives, Rogerson (2004) draws our attention to the fact that the existing government SMME programmes have largely been biased towards the group of medium and small sized enterprises and, to a large extend have bypassed micro enterprises and the informal economy (Rogerson, 2004). It is worth noting that a significant proportion of African immigrants operate in this sector.

Regardless of the positive and negative outcomes of the South African government's SMME initiatives mentioned above, one finds a distinct group of entrepreneurs (African immigrants) with unique needs who are totally or partially bypassed by these policies.

\section{Problems faced by African immigrant entrepreneurs}

Immigrant entrepreneurs face a number of challenges when starting their business and again as they try to grow or stay afloat.

Reporting on the obstacles that African immigrant owned businesses encountered during the business start-up phase, Tengeh (2011) noted the following:

- $77,0 \%$ indicated limited finance as an obstacle;

- $54,8 \%$ reported lack of business space as an obstacle;

- $39,3 \%$ reported lack of appropriate residence permits as a major business start-up obstacle;

- $29,6 \%$ placed emphasis on insufficient demand as a start-up obstacle;

- $21,5 \%$ acknowledged lack of expertise in the concerned business area as an impediment;

- $10,4 \%$ reported lack of information on business-related matters as an apparent business start-up obstacle and;

- $4,4 \%$ reported lack of skilled employees as an obstacle.

Based on the above results, it can be drawn that the three most cumbersome obstacles confronting African immigrant entrepreneurs are finance, business space, and residence permits. Once started, (Tengeh, 2011), further noted the persistence of the foregoing obstacles at the operational level.

\section{Rationale for SMME support}

According to Agupusi (2007), the promotion of SMMEs for poverty reduction in developing countries has been gathering momentum among governments and international development agencies. The small business development literature argues that SMMEs make unique contributions to the economy, with a contribution to GDP, employment and poverty reduction being the most stated (Biggs, 2001). According to Cobweb Information (2007), development partners now see SMMEs as an important part of their work and believe that assisting more firms to start and grow has an impact on 
economic growth and poverty reduction. Liedholm (2001) adds that the different types as well as the different members of the SMMEs group have different contributions to make to the dual objective of economic growth and poverty alleviation.

The literature on the support SMMEs can be further re-grouped into two: those in favour of SMMEs support (proSMMEs) and those against SMMEs support (anti-SMMEs).

\section{The Pro-SMME debate}

Researchers on this 'side of the fence' believe that SMMEs should be supported on the basis that they are victims of market and institutional failures that bias the size distribution of firms, and therefore intervention would level the playing fields (CDE, 2004; Beck \& Demirguc-Kunt, 2004). On this same side of the fence, others push the support agenda based on the fact that SMMEs possess certain characteristics that give them a competitive advantage when it comes to promoting economic and social development (Joubert et al, 1999; Ntsika, 2000; Dockel 2005; Agupusi 2007). These characteristics include job creation, innovation, income distribution and so forth. On the basis of these inherent characteristics, the job generating ability of SMMEs is seen as the single most important reason governments and policy makers should discriminate in favour of small businesses (Joubert et al, 1999; Ntsika, 2000; Luetkenhorst, 2004; Dockel, 2005; Jeppesen, 2005; Agupusi, 2007).

The aforementioned line of thinking emerged when empirical research by David Birch in the USA revealed that small businesses create most of the jobs (Biggs, 2001; Audretsch \& Thurik, 2003; Gebremariam et al, 2004). According to the US Business Administration, small enterprises created $76 \%$ of net new jobs from 1990 to 1995 and $75.8 \%$ from 1996 to 1997 (Acs, 2001). It is worth noting that most research on the role SMMEs as far as job creation is concerned has always excluded micro size enterprises. Would the results of these studies change if micro enterprises were partly distinguished as a separate component of the SMME group with unique characteristics? Of course the answer may be a resounding 'no'. Assuming that SMMEs contribute to employment, Von Broembsen and Wood (2005) note that they do not contribute proportionately. Recent studies that have addressed the concerns of micro and small enterprises include those of Ntsika (2000), Liedholm (2001) and Harvie (2003). According to Harvie (2003), in Asia micro enterprises account for more than $60 \%$ of all regional enterprises and up to $50 \%$ of paid employment.

Focusing on Latin America and Africa, Liedholm (2001) notes that, small and micro size enterprises are a major source of livelihood for a significant proportion of the population. In South Africa, where micro enterprises form part of the SMME group, Ntsika (2000) observes that they play an important role in job retention rather than job creation. Nonetheless, Agupusi (2007) is optimistic that given the chance, some of these micro enterprises would grow and even graduate to small enterprises.

Besides employment, the contribution of SMMEs to economic growth (Ntsika, 2000; Sinhna, 2003) as well as the income distributional role (Luetkenhorst, 2004; Jeppesen, 2005) of SMMEs is highlighted by some pro-SMME support researchers. According to Gebremariam, et al (2004), SMMEs and most importantly micro enterprises are credited most for providing employment opportunities and income to people at grassroots levels especially women, while also encouraging indigenous investment. Consequently, there is an increasing policy focus on the need to strength entrepreneurship and the contribution of micro enterprises to attain economic growth with equity, as well as to address gender and poverty reduction issues (Harvie, 2003). Pressure to attain such outcomes has been further increased in the wake of the 2009 global financial and economic crises.

While acknowledging that, micro enterprise and survivalist activities have absorbed large numbers of unemployed people in the South African, the DTI (1995) argues that they are in themselves not always able to generate reasonably remunerated long-term jobs. In this respect, the DTI (1995) suggests that support for SMMEs has to include steps to upgrade the skill levels of operators and strengthen the use of appropriate technologies in order to boost their capacities to create long-term jobs.

\section{The Anti- SMME support debate}

Sitting on the other 'side of the fence', some researchers have increasingly argued against SMME support. Synthesizing their arguments with respect to SMMEs and their contribution to economic and social development, the following conclusions may come to the fore. Although well founded economic reasoning supports the case for employment creation by SMMEs (Joubert et al, 1991; Agupusi, 2007), researchers sitting on this 'side of the fence' have argued that SMMEs do not produce the bulk of employment opportunities (Biggs, 2001), do not contribute significantly to economic growth, neither do they foster income distribution or reduce poverty (Ayyagari, et al., 2003, Beck \& Demirgue-Kunt, 2004). 
Furthermore, and from an employment standpoint, this school of thought maintains that SMMEs do not produce most of the jobs in the economy since they also have a considerably high dissolution rate as compared to large enterprises (Acs, 2001; Biggs, 2001; Chandra et al, 2001). They argue that it is not the size of the firm that matters but rather, how long the firm has existed (Acs, 2001). The size dimension used as indicated by the number of employees is static and gives a short term scenario. On the other hand, age suggests a longer term scenario and gives a better indication of growth and/ or survival. In terms of the quality of jobs created, empirical evidence from both developed countries and developing countries suggests that large firms offer higher wages than small firms, even when differences in worker education and experience and the nature of the industry has been considered (Biggs, 2001).

Biggs (2001) maintains that even in the case where both large firms and small firms generate a proportionate number of jobs, it appears that the social benefits and job security in the former often exceed those of the latter. Audretsch and Thurik (2003) concur with Biggs but argue further that while SMEs generate employment at a lower wage in the managed economy; in the entrepreneurial economy SMEs create both more jobs and higher wages. As far as the claim that SMEs are more labour intensive than large firms, on a closer look this claim does not hold true as empirical evidence suggests that firm size is not a pre-determinant of labour intensity (Biggs,2001).

From an African standpoint and more importantly South Africa, Dockel (2005) argues that although the SMEs death rate is high, the more new entrants (new firms), the greater the chance that some will survive and grow, hence contributing to employment. According to Acs (2001), most of the new jobs come not only from new firms but also from new branches of existing large firms SMMEs. Likewise, it is universally accepted that there is a link between small business growth and economic growth. From an economic growth point of view, the question often asked is whether the creation and growth of SMEs (or SMMES) leads to economic growth or whether it is economic growth that spawns more SMEs. In an attempt to answer this question, Ayyagari, Beck and Demirgue-Kunt (2003) reviewed the contribution made by SMEs to economies in 76 countries. The study is said to have rekindled a lively debate as well as controversy around the contribution of SMEs to growth, employment and poverty reduction (Luetkenhorst, 2004). According to the Ayyagari, et al study, in low-income countries just $18 \%$ of the population was employed by SMEs (Cobweb Information, 2007). The results of this study suggest that the positive association between SME development and economic growth is not statistically robust and moreover the evidence does not support a significant relationship between SMEs and poverty reduction (Luetkenhorst, 2004). The study furthermore warns against discriminating policies in support of SMEs, but rather for policies that make the business environment conducive for both SMEs and large firms (Beck \& Demirguc-Kunt, 2004). At the level of the methodology, the design of the study has been questioned on grounds of SME variability chosen (Luetkenhorst, 2004). In other words, different SMEs are lumped together with a little indifference shown with regards to their nature, sector or characteristics. At one level, this study has been criticised for restricting the sample to people whose records existed and therefore it only covered those employed by businesses in the formal sector (Cobweb Information, 2007). As far as this study is concerned, one may logically argue that the results may tell a different story if micro enterprises were included in the sample.

Drawing from the first two schools of thought, the author may suggest a third. The hypothesis behind this line of reasoning is the fact that self-employment in the formal, as well as the informal, sectors of the economy is the best way to go in poverty eradication. The logic here is that, what matters most to an entrepreneur (would-be business owner) is the fact that he or she wants to improve or create an income for himself/herself, and generating jobs for others is secondary. Under this circumstance, the goal of creating jobs would be much simpler if everyone was an entrepreneur and support was readily available. It may be argued that although micro enterprises may sometimes not create permanent jobs or provide decent wages, they nonetheless provide jobs. This is the case when a micro enterprise hires another micro size enterprise (Nichter \& Goldmark, 2009) thereby providing work for their self-employed peers.

Regardless of the arguments put forward for and against the support of SMMEs, there is however a consensus on some basic points. Firstly, it is universally acknowledged that SMMEs as well as large businesses can only prosper within a healthy economy and a conducive overall policy framework (Luetkenhorst, 2004). Secondly, it is equally agreeable that the ability of any businesses to generate new jobs seems to be greatly dependent on certain macroeconomic variables, including the businesscycle (Liedholm, 2001). In this regard, Bannock (1981) accredits SMMEs for being more resilient to depression and therefore able to offer a steadier level of employment than large ones. Liedholm (2001) adds that this results from net firm creation rather than from net firm expansion. In the USA for instance, Acs (2001) notes that small businesses create most of the jobs in America during a downswing, whist the converse is true for big enterprises during an upswing.

Jeppesen (2005) warns that regardless of the reasons behind the promotion of SMMEs (including economic, social or political), the SMME tier should be scrutinised to see if it delivers in line with the specific objectives. It may be 
concluded that SMMEs contribute to economic and social development through the following (Harvie, 2003): employment; income distribution (Chalera, 2006); power distribution; investment distribution; innovation; entrepreneurship (Ntsika, 2000); and maximisation of scare resources.

\section{Why Support African Immigrant- Owned Businesses?}

There are many reasons why immigrant-owned businesses may need support. Such reasons become relevant when one looks at immigrant-owned businesses on two fronts, namely the business itself and the owner of the business.

\section{African Immigrant-owned businesses as victims}

As mentioned in the preceding section, the 'blocked mobility theory' enforces the view that immigrants are discriminated against in various domains. Under these circumstances, immigrant entrepreneurs usually start on a small scale, and most likely in industries where entry is easy and the capital outlay is minimal. It comes as no surprise that immigrant-owned businesses usually fall within the SMME cluster.

Pertaining to the start-up and operation of immigrant-owned businesses, assuming that the argument forwarded by pro-SMMEs lobbyists is true, there should be a strong motivation for the support of immigrant-owned businesses. However, a more immigrant focused argument in favour of support may be based on the following factors:

- On the 'heroic front' some authors have argued that immigrants are more entrepreneurial than natives. This is based on the premise that immigrants bring with them certain entrepreneurial characterises, and have a unique ability to mobilise resources.

- On the 'victim front', studies increasingly argue that immigrant businesses in certain countries are underperforming and, given proper support, they could assume their positions as engines of growth and employment.

Acknowledging that most immigrant businesses generally fall under the umbrella of SMMEs, Pinkowski (2009) argues that treating ethnic businesses the same as mainstream businesses is not equal treatment, because they have different issues and challenges that should be addressed by public policy in order to truly address equal opportunities.

In a study of immigrants and refugees in Durban (South Africa), Maharaj (2009) concluded that the problems facing immigrants and refugees can be divided into three categories:

- Legal (asylum determination, security of person, documentation)

- Socio-economic/social assistance (health, education, employment and shelter)

- Cultural and economic integration and xenophobia (Tlou, 2004:44 cited in Maharaj, 2009:8).

\section{African Immigrants as consumers or producers}

Another way to look at why immigrant-owned businesses need support is when one looks at an immigrant as an either a consumer or producer. Assuming a hypothetical economy where an immigrant is either a consumer or a producer, the following choices would be imminent. In an efficient scenario, option one would be feasible if the producers (the working class) can shoulder the entire burden of the non-producers (consumers). That may be the case in countries where refugees and asylum seekers are given stipends and are not allowed to participate in any economic activities. Here the rational lies in the fact that taxpayers (producers) can bear the burden. However, the ability to maintain such a situation would depend on the productive capacity of the country concerned and the number of immigrants (asylum seekers and refugees, inclusive).

Option two is the second scenario that may be applicable to South Africa, where immigrants, the bulk of which are refugees and asylum seekers, are permitted to actively participate (although technically constrained by other factors mentioned earlier) in the economy. This scenario is important where unemployment thrives and therefore taxpayers are not able to support the numbers of immigrants. One may therefore argue that promoting and supporting immigrant businesses would be the best route to take, as this would increase employment as well as broaden the tax base. South Africa has the choice to either see the preponderance of these immigrants as a problem or turning the situation into a positive one. There are successful cases of the latter that South Africa can draw from. 


\section{Lessons Learned from Case Studies}

The lessons that can be gleamed from the international experiences of countries in dealing immigrants in general and immigrant entrepreneurship will be discussed with the following themes in mind:

- Measures that encourage immigration

- Measures to stimulate the integration of immigrants into the host labour markets

- Measures to promote access to entrepreneurial resources.

\section{The case of Portugal}

As noted by Oliveira (2008b:2-4), Portugal has in the past years implemented several measures aimed at increasing the integration of immigrants into the labour market, as listed below:

- In relation to security of employment and workers' rights for immigrants, Portugal fully meets international best practice, as set out in the Migrant Integration Policy Index (MIPEX Index).

- Immigrants in Portugal are eligible to accept most jobs and may start a business, contributing to Portugal's achievement of $83 \%$ in the MIPEX Index in the area of eligibility.

- Immigrants' working rights are enshrined in article 59 of the Portuguese Constitution which establishes that workers enjoy economic rights, without distinction as to "age, sex, race, citizenship, country of origin, religion, and political or ideological convictions." Undocumented migrants have specific rights in terms of access to health, education and redress for victims of trafficking.

Recognising that more still needs to be done in terms of labour market integration, the Portuguese government included eight measures related to employment and professional training (but several other measures under other areas also relate to this aim) in its Plan for Immigrant Integration, namely:

- Specific vocational training for immigrants

- Awareness-raising campaigns on health and safety at work;

- Increased inspections of illegal employment

- Promoting social responsibility for immigrant integration among employers and co-workers

- Pro-integration training measures

- Promoting trade union membership among immigrants

- Promoting immigrant entrepreneurship.

Since the implementation of the above plan, Portugal has seen an increase in the numbers of international students studying at its universities and graduating with valuable skills. Providing the mechanisms for these graduates to remain in Portugal to work in high-skilled jobs is a priority for labour market integration policy (Oliveira; 2008).

Furthermore in the Portuguese government's Plan for Immigrant Integration, agreed on in May 2007, the Ministry for Employment and Social Security committed to providing intercultural and anti-discrimination training for the staff of the Institute of Employment and Professional Training, as well as to raise awareness among the business community of the need to welcome and integrate immigrant workers.

The Ministry also established training and job creation schemes to facilitate immigrant integration into the labour market. Noted under these schemes are:

- The National Immigrant Support Centre runs an Employment Support Office for immigrants.

- Many of the immigrant job centres are located in districts with high numbers of immigrants.

- The National Immigrant Support Centre also supports immigrant entrepreneurship through a partnership with the National Association for the Right to Credit.

\section{Conclusion}

In the past justification for the institution of support policies in favour of small businesses was based on the fact that they disproportionately encountered more obstacles than their larger counterpart. Shying away from the traditional "business focus" justification for the support of small business, this study advances an "owner focus" justification. One that may be based on the unique needs of the owner rather than that of the business. Following similar logic, given that most 
immigrants start small businesses as a means of survival in their host countries, this study advances an even more compelling reason immigrant owned businesses should be supported.

In view of the increasing levels of international migration, most governments are on the guard as they evaluate the impact of immigration on their economies. While on the one hand they have to meet up their international obligations, on the other they have to respond to the overwhelming pressure from their masses for employment. In response to the pressure for economic growth, employment and poverty reduction they lose sight of the role that immigrant entrepreneurs (often viewed as being part of the problem) can play in the process. Acknowledging the role that a supported small business sector in general and immigrant owned-businesses in particular can play in the economy and taking steps to strengthen this sector would be in the right direction.

\section{References}

Acs, Z. (2001). The Job Factory. Inc. 23(7) 40-41.

Agupusi, P .(2007). Small Business Development and Poverty Alleviation in Alexander, SouthAfrica. Second meeting of theSociety for the Study of Economic Inequality. Berlin.

Ayyagari, M., Beck, T. \& Demirguc-Kunt A. (2003). Small and Medium Size Enterprises across the Globe: A New Database. World Bank, Mimeo.

Bannock, G. (1981). The Economics of Small Firms. Oxford, Basil Blackwell.

Biggs, M.. ( 1997). Getting into GEAR: government and the economy. Cape Town: UCTPress.

Beck, T., Demirguc-Kunt, A.\& Peria, M. (2005). Reaching out: Access to and use of Banking Services across Countries. World Bank Policy Research Working Paper 3754, October.

Brinders. J., Mamela, B.\& Mlosy, C D. (2003). African Renaissance 2003: Entrepreneurship and Small Business Management Development in Africa.Paper presented at theInternational Trade Conference addressing New Partnerships for Africa's Development (NEPAD) priorities. Port Elizabeth, 22-24 October 2003.

CDE (2004). Key to Growth: Supporting South African emerging entrepreneurs. Reportnumber 12, Johannesburg.

Chalera, C. S. (2006). An Impact Analysis of South Africa's National Strategy for theDevelopment and Promotion of SMMEs. Unpublished PhD thesis, University ofPretoria.

Chandra, V., Moorty, L., Nganou, J., Rajaratnam, B. \& Schaefer, K. (2001). Constraints to Growthand Employment in South Africa. Report number 2, World Bank.

Cobweb Information (2007). "Does Entrepreneurship Lead to Economic Growth? AnUnanswered Question." Gateshead: Cobweb.

Dockel, M. (2005). SMMES: do they live up to the expectation? Management Today,Yearbook: 58-61, March.

Dallago, B. (2003). The importance of Small and Medium Size Enterprises. UN Chronicles,(4): 1.

Department of Trade and Industry (DTI) (1995). National Strategy for the development andPromotion of Small Business in South Africa. Second and final print. March. Pretoria

Fatoki, O. \& Patswawairi, T. (2012). The Motivations and Obstacles to Immigrant Entrepreneurship in SouthAfrica. Journal of Social Sciences, 32(2): 133-142

Luiz, J .(2001). Small Business Development, Entrepreneurship and Expanding the BusinessSector in a Developing Economy: the Case of South Africa. The Journal of AppliedBusiness Research, 18 (2): 1-16.

Ntsika (2000). State of Small Business in South Africa. Annual Review, Pretoria,Department of Trade and Industry.

Maharaj, B. (2009). Migrants and Urban Rights: Politics of xenophobia in South African cities.L'Espace Politique, (8)1-15. http://www.espacepolitique.revees.or/index1402.html. [12 May 2010]

Gebremariam, G., Gebremedhin, T. \& Jackson, R. (2004). The role of small business ineconomic growth and poverty alleviation in West Virginia: an empirical analysis. Selected paper prepared for presentation at the American Agricultural EconomicsAssociation Annual Meeting, Denver, Colorado, August 1-4 2004.

GEM (2004). Global Entrepreneurship Monitor: South African Report. Cape Town: UCTGraduate school of business, University of Cape Town.

Hansohm, D.(1992). Small industry development in Africa - Lessons from Sudan. Hamburg,Lit Verlag.

Harvie, C. (2003). The Contribution of Micro-enterprises to Economic Recovery and PovertyAlleviation in East Asia. Economic Working Paper Series, University of Wollongong.New South Wales.

Harvie, C. ( 2005). The Contribution of Micro-Enterprises to regional economic recovery andpoverty alleviation in East Asia. In: Harvie, C. and Lee, B. (eds). Sustaining Growthand Performance in East Asia: the role of Small and Medium sized Enterprise.Edward Elgar, Massachusetts: 72-98.

Lloyd, H. (2002). Small and Medium Enterprises (SMEs): Instruments of Economic Growthand Development in a South African Regional Dispensation. Port ElizabethTechnikon, South Africa.:1- 25. http://ideas.repec.org/p/wiw/w.wrsa/ersa02p464. htm\#download. [3 September 2007]. 
Jeppesen, S.(2005). Enhancing Competitiveness and Securing equitable development: canSmall Micro and Medium-Sized Enterprises (SMMEs) do the Trick?Development inPractice, $15(3,4): 463-474$, June.

Joubert, C., Schoeman, N. \& Blignaut, J. (1999). Small, Medium and Micro-size Enterprises(SMMES) and Housing Construction Industry: a Possible Solution to South Africa'sSocio-Economic Problems. SAJEMS NS, 2 (1): 22-33.

Landau, L B. (2010). Discrimination and Development? Urbanisation and sustainablelivelihoods in Johannesburg. In: Crush, J. \& Frayne, B. (Eds.). Surviving on theMove: Migration, Poverty and Development in Southern Africa. IDASA, Cape Town: 66-82.

Landau, L. B \& Jacobsen, K (2004). Refugees in the New Johannesburg. Forced MigrationReview (FMR):44-46.

Luetkenhorst, W. (2004). Economic development, the role of SMEs and the rationale fordonor support: some reflections on recent trends and best practices. Keynotepresentation at the SME partnership group meeting held in Hanoi on the 19November, 2004. http://www.unido.org/fileadmin/import/40525_unidowl.doc.

Maharaj, B. 2004. Migration to Post-Aparthied South Africa. Global Perspectives, (1):1-7,June. http://www.gcim.org. [10 April 2009].

Maharaj, B. (2009). Migrants and Urban Rights: Politics of xenophobia in South Africancities. L'Espace Politique, (8)115.http://www.espacepolitique.revees.or/index1402.html. [12 May 2010]

Molapo, S., Mears, R R. \& Viljoen J M. (2008). Development and reforms in small businesssupport institutions since 1996. Acta Commercii: 27-40.

Nichter, S. \& Goldmark, L. (2009). Small Firm Growth in Developing Countries. DevelopmentAlternative, Inc. Morocco: 1-36, February.

Oliveira, C. R. 2008b. The Determinants of Immigrant Entrepreneurship Strategies in Portugal.Migracoes, 3:101-128.

Pinkowski, J.(2009). Challengesand promises for Immigrant Entrepreneurship in Dublin.Dublin City Council Economic Development Unit:1-63, May.

Rogerson, C. M. 2004a. Pro-poor Local Economic Development in Post-Apartheid South Africa: the Johannesburg Fashion District. Paper presented at the 50th Anniversary Conference: Reviewing the first decade of development and democracy in South Africa. International Convention Centre Durban. 21-22 October.

Rogerson, C. M .(2006). Developing SMMEs in Peripheral Spaces: The Experience of theFree State Province South Africa. South African Geographical Journal, 88(6) 66-78.

Rogerson, C. M. (2007). Small enterprises in the tourism sector: opportunities and challenges Draft report prepared for SEDA: 1 88, May.

SACOB (1999). Developing the small business sector in South Africa: A Review ofRegulatory and Other Obstacles. Pretoria.

SA Presidency (2008). Towards a Fifteen Year Review. SA presidency, Pretoria, October. http://www.thepresidency.gov.za/pebble.asp?relid=521.

Sinha, A .(2003). Experience of SMEs in South and South-east Asia. South Asia Enterprise Development Facility: 1-18. 2009]. December. www.bei-bd.org/downloadreports/publicationdownload/57/download. [10 August

Swanepoel, E. (2008). The effect of the interventions of the South African Breweries' kickstart youth entrepreneurship programme on entrepreneurial and small business performance in South Africa. Unpublished PhD dissertation. University of South Africa.

Tengeh, R., Ballard, H. \& Slabbert, A.(2011). A Framework for Acquiring the Resources Vital for the Start-up of a Business in South Africa: an African Immigrant's Perspective. European Journal of Social Sciences, 23(3):362-381.

UNDP (2003). The challenge of sustainable Development in South Africa: unlocking people'screativity. South Africa Human Development Report UNDP South Africa, OxfordUniversity press: 1-16.

Von Broembsen, M. \& Wood E.(2005). Who provides South Africa's jobs? In: Von Broembsen, M., Wood, E. \& Herrington M. (eds) General Entrepreneurship Monitor. South African Report: 23-30. Cape Town: UCT Graduate school of business, University of Cape Town.

Waldiger, R., Aldrich H. \& Ward, R.(1990). Ethnic Entrepreneurs. Sage, London. 
